\title{
Women as Activists in Indian National Movement: Role of Educational Institutions in Uttar Pradesh
}

\author{
Ruchi Verma \\ (School of International Studies/ Jawaharlal Nehru University New Delhi/India)
}

\begin{abstract}
India's struggle for independence is of tremendous importance in the history of anti-colonial movements. However, the most important aspect of this movement for independence from a historical point of view was that it saw mass participation by Indian women, women who had till then been confined to the domestic sphere. Their contribution in the independence movement is very significant. They were involved in diverse nationalist activities, both within and outside the home. Education is viewed as a means to enhance the social presence of people and enable them to adapt to a changing external situation. This paper will primarily focus on the role of educational institutions in initiating women to take part in the freedom struggle. This paper will also explore the nature of involvement and the impact made by the involvement of women in the freedom struggle. The role of education and educational institutions can't be neglected. It helps the women to shed their fears and come in the forefront. The patriotic feelings and teachings of the institutions develop a sense of self confidence among women and lead them to fore front. Though due to inadequate mention of their contribution in the historical literature their sacrifice remained unrecorded but there is no neglecting of the fact that these women's through their participation accelerated the pace of nationalist struggle and drive the British out of the country.
\end{abstract}

Keywords: Women, Education, Educational Institutions, Indian National Movement

\section{INTRODUCTION}

India's struggle for independence is of tremendous importance in the history of anti-colonial movements. However, the most important aspect of this movement for independence from a historical point of view was that it saw mass participation by Indian women, women who had till then been confined to the domestic sphere. Their contribution in the independence movement is very significant. They were involved in diverse nationalist activities, both within and outside the home. They held meetings, and demonstrations, took part in Satyagraha, picketed toddy and foreign- cloth shops, went to prison and also suffered brutalities at the hands of the British police.

Education is viewed as a means to enhance the social presence of people and enable them to adapt to a changing external situation. However, before 1920's efforts were made towards the education of women but it mainly focuses on improving their skills in domestic sphere. But later the attitude changed. Now the education of women was seen as a subject referring to widening horizon and the individual empowerment. By this time the slogan of Indian leaders and social reformers had come to be: educating a girl means educating a family.

Though there was no talk of emancipation of women's but there was a general belief that women should be educated and be encouraged to work outside the home. And the women themselves imparted a new sensibility to members of the younger generations. Women invested the freedom struggle with a rare flavour of homeliness and unbending determination. Gandhi had generated a pride and a passionate involvement in winning swaraj among the women. Spinning Charkha has thus become a means to identify themselves as an activist in the activity of national movement for the women. They now have become much more confident after entering into the public sphere and widening their horizon. They were now not afraid of extremities.

Though closely associated with women's public participation were the issue of segregation and respectability, which were important aspects within the domestic sphere. Women used segregation and respectability to enhance the political effectiveness of their activities as well as serve the nationalist agenda. The nationalist rhetoric for respectability translated any act done on 'behalf of the nation' as respectable-even if that involved women coming out of purdah. The institution of purdah in India was (and still is) a form of segregation of the sexes practised within the domestic sphere, and when women began to participate in political demonstrations they maintained features of purdah such as keeping their heads covered, or by performing selective nationalist activities in women-only groups. It was also the first occasion when woman was exposed to a male dominated public sphere for themselves within the male-dominated public domain. However, public participation of women was limited and dependent on family dynamics within the household. In conjunction with the domestication of the public sphere there was the parallel process of politicisation of the domestic sphere. For many women, social constraints during the nationalist period did not allow any form of public 
activity. Yet, events in the public sphere, at the heart of political conflict, were affecting women's lives within the domestic sphere. It was necessarily not the individual but the whole household which got involved in the movement. When members of their families become participants in the movement, women had to adapt to the changes brought about by the nationalist movement. Women maintained traditional roles and virtues, yet supported their husband's nationalist activities and raised their children, symbolically referred to as 'children of the nation'.

\section{NATURE OF INVOLVEMENT}

In the UP, the participation of women in the Indian National Movement was substantial and of highly variegated nature. They were involved in meetings, demonstrations which were often held in defiance of governmental orders. In the rural areas of Awadh there were all-women's meeting and attempts to form women's panchayats in the mid 1920's. During the 1930's, with women entering the legislatures, agitational politics was combined with some amount of constitutional activity. Women also understood the enigmatic Individual Satyagraha campaign launched by Mahatama Gandhi and showed keenness to offer themselves for arrest. In the Quit India Movement of 1942, the women of UP were involved at various levels of the underground movement, from crucial policy making to providing infrastructural and moral support.

Even though many women come into the movement because of their husbands or sons, their subsequent involvement had a degree of autonomy. There was a significant change in the quality of these women lives. The national movement created a social and political space within which women lives changes in a positive direction. It became possible for them to step out of their homes more easily. Women were also able to avail the educational opportunities that were emerging at this time. More importantly, it was recognised that women too could have a political sensibility.

It was also evident in some cases in which women put moral pressure on their menfolk to participate in the movement. When women were in the forefront of political agitations, the authorities were more hesitant to resort to repressive action. Often, the arrest of a woman had an electrifying effect on the people who would then turn out in larger numbers to participate in protest meetings and demonstrations. The empowerment of women was also depicted in the literature and novel of that time. Prem Chand was a famous writer of Uttar Pradesh and his stories written during that time also shows the change in attitude of women. In one such Story of his, titled "Wife into Husband", he shows the influence of wave of Nationalism and Gandhi's teaching over women.

\section{ROLE OF EDUCATIONAL INSTITUTIONS}

However, The Hindi speaking areas had largely remained unaffected by the nineteenth century debates and initiatives for women's education in British India that had taken place mostly in the Bengal and Bombay Presidencies. The few schools run by women Missionaries had failed to attract girls from Hindu and Muslims families, who feared attempt at conversion.

Though, middle and higher education for girls grew substantially when non-sectarian and nonmissionaries schools for girls were set up in the 1920's, with the teaching being almost exclusively in the vernacular. Hindi played a more prominent role in the girl's education than that of the boys. Reformers considered it as the ideal language for women's education. Moreover as more and more women received formal education, they became conscious of their problems and social status and sought to improve their situation. Women leaders in the early twentieth century were, by and large, educated, and belonged to the families deeply involved in the either in the social reforms or in the independence movement. However, to discuss various issues several women organisation came up. In fact, an All India Conference on education and social reform, was held at Poona in January 1927, which set up the All- India Women's Education Fund in 1929 with a view to promote education among girls and women.

By the 1930's, there were lively discussions on the quality of education to be imparted to girls. There were different sets of opinion regarding that. The generally accepted norm was to have a separate curriculum for girls with emphasis on the development of household skills and proficiency in drawing, painting and music. Though the other group including Rameshwari Nehru, feels that education for women should be broad based. As it was not enough for a women to be educated so as to become a good wife and a good mother- the education she received should also help her to become good citizen. Being equipped to earn a livelihood was important. Thus, girls should be taught a crafts as boys were.

The main educational institutions, which attracted girls, were Kanya Mahavidhyalaya in Jalandhar, Crosthwaite High School and Prayag Mahila Vidhyapith in Allahabad, Isabella Thoburn School and college in Lucknow and Indraprastha Girl's High School and College in Delhi. One of the prime aims of these institutions was to prepare the girl's for the public role. Women of these institutions were regularly taken to the annual sessions of Indian National Congress, where they were given the opportunity to deliver the speech. It was the patriotic atmosphere of the Mahavidhalaya, Crosthwaite school and Mahila Vidhyapith in Allahabad which 
became a prelude to political participation and activity during Non Cooperation Movement and Civil Disobedience. National leaders often came to speak at both the schools and colleges.

In fact, the schoolteachers were also the source of exposure to nationalist ideas. Those who studied in nationalist institutions like Banaras Hindu University would find their whole life transformed. The Gandhian groups used to come to the hostels and wake the students up at $5 \mathrm{am}$. Then they would form a circle and as in warandha, sing prayers and spin the charkha. Students thereafter would go back to their rooms and get ready for their classes. On Sundays they would go neighbouring villages and teach the village women and children besides explaining the virtues of hygiene and nutritious food. There were also cases of students learning different cultures, languages as part of the national integration. The number of educational institutions in Uttar Pradesh as well as the students enrolled in them increased between 1920's and 1930's. Allahabad University emerged as the home to many prominent political and literary figures. 'Services as slaves' referred to the Indians who sought employment with the British raj. The rise of incidence of unemployment among the educated youths also increased the count of people available for political work.

Thus, the idea that was repeatedly emphasised was the importance of women's education for national development. Education was also considered to be important for producing good mothers and wives and it would enable women to bring about reforms within their homes. Also it would enable women to produce and educate healthy progeny for the nation. This would align their domestic responsibilities more closely with political demand of the nationalist movement. Moreover, women's education would facilitate the construction of a strong and stable national identity. It was argued that a nation was progressive when women acquired qualities such as patience, devotion and self-sacrifice, and regressive when women were drowned in ignorance. As Aristotle has said, “on the auniti (progress) or avnati (regress) of women is dependent the nation's progress or regression. Women's education would lead to national regeneration and the elimination of the practice of child marriage, which was seen as a cause for the degradation of Indian women and a reason for India's political dependence.

Since there was an obvious correlation between education and the growth of a nationalist consciousness, the more significant fact was that women became more politically aware, and their thrust for education increased. The trajectory of many nationalists was one of constantly pursuing formal knowledge along with greater and greater nationalist involvement. Somehow it was felt that more education would make them better nationalists. Stints in jail were also often considered conducive to scholarly pursuits because jail-life gave them the leisure to devote time to reading and also threw them in the company of more educated women.

Nationalist participation enabled women, and also male nationalist leaders, to see their demonstrable as well as latent political potential. The public sphere offered a challenge and an exciting alternative to tradition bound domestic lives and enabled women to experience a new sense of freedom. Women who had been in purdah managed not only to step out on streets but also engage in public activities. Women for the first time found that they could associate with other women without the supervisory gaze of the males in their families. Women had believed in the nationalist promises of freedom and justices and they were not about to let the new state renege on these promises. Instead, they used the opportunities that arose with new nationalist expectations to develop a distinct political awareness and consciousness.

\section{REVIEW OF LITERATURE}

In the book "Indian Women and Nationalism: The UP Story" by Visalakshi Menon, she mentioned about the territories where women's political participation was evident. She also dealt with the question of women's autonomy-their creation of individual spaces within a highly structures movement. She also talked about the role of education and educational institutions briefly. In the article "Women in the Frontline: the case of UP" by Uma Rao, she mentioned that there was no immediate personal gain for the women who came out to fight for Swaraj nor could they have foreseen the distant possibility of any opportunity. They braved official repression and accepted personal sufferings, including parting from the children, for the romantic ideal of Swaraj. Radha Kumar in his book "History of doing: An illustrated account of movements for women's rights and feminism in India, 1800-1900", presents the story of Indian women from the $19^{\text {th }}$ century to the present times. His work deserves credit for illustrations provided in almost every chapter, and for the presentation of old and new documents, excerpts from letters and from informal writings. He examines the foregrounding of the women's issues during the reform and nationalists movements and its subsequent disappearance from the agenda of public debate. Kapil Kumar article "Rural women in the Oudh 1917-47: Baba Ramchandra and the women question" is the only piece of work that studies political activism among the women of Awadh. This article consists of five sections, dealing with the oppression of peasant women and their personal experiences, various issues related to the women, political awakening amongst them, and finally their participation in the freedom movement. But Kapil Kumar never seems to questions Ram Chandra. There is no mention of the women's response to Ram Chandra's exhortion or the effect that his leadership had on them individually or as a group. Suruchi Thapar's article "Women as activists: Women as symbols: A study of Indian Nationalist 
Movement" though has not taken up the academic debate on misrepresentation of women in historical records, it has tried to show that the success of political movements is dependent on women's contribution. The Indian nationalist movement benefited not only from the nationalist activities of women but also from the way it confined its women to various constructs and role-models. Suruchi Thapar- Bjorkert in her another article "Nationalist Memories: Interviewing Indian Middle Class Nationalist Women" has moved away from homogenising and unified traditions, which saw elite women as representative of the entire movement. She had interviewed ordinary middle class women. She wanted to explore the diversity of women's activities, their varying political consciousness and the conflicts they encountered during the course of their participation. She also analysed that whether the projection of women as 'nationalist heroines' or 'women in the front-line' was a true representation of the movement. Suruchi Thapar Bjorkert in her book "Women in the Indian National Movement: Unseen faces and Unheard Voices 1930-1942" reveals the fact that women expressed different motivations for participation. She also brings out the point that many women later go back to their domestic responsibilities as for them bring up new generation was more articulate, more conscious of their rights as women.

\section{CONCLUSION}

Thus, at last it can be said that the role of education and educational institutions can't be neglected in the national movement. It helps the women to shed their fears and come in the forefront. The patriotic feelings and teachings of the institutions develop a sense of self confidence among women and lead them to fore front. Though, due to inadequate mention of the contribution of these educational institutions and due to lack of data, in the historical literature their sacrifice remained unrecorded. But there is no neglecting of the fact that these institutions helps in igniting the fire of nationalism in the heart of women, who through their participation accelerated the pace of nationalist struggle and drive the British out of the country.

\section{REFERENCES}

Books:

[1] Menon, Visalakshi, Indian Women and Nationalism: The UP Story (New Delhi: Shakti Books, 2003).

[2] Thapar- Bjorkert, Suruchi, Women in the Indian National Movement: Unseen Faces and Unheard Voices, 1930-42, (New Delhi: Sage Publications, 2006).

[3] Rubin, David, Widows, Wives and Other Heroines: Twelve Stories by Premchand (translated) (Delhi: OUP, 1998).

[4] Kumar, Radha (1993), The History of Doing: An Illustrated Account of Movements for Women's Rights and Feminism in India 1800-1900 (New Delhi: Kali for Women, 1993).

[5] Kasturi, Leela and Mazumdar, Vina (ed.), Women and Indian Nationalism (New Delhi: Vikas, 1994).

[6] Rao, Uma, Women in the Frontline: the Case of UP in Leela Kasturi and Vina Mazumdar (ed.) Women and Indian Nationalism (New Delhi: Vikas, 1994)

[7] Kumar, Kapil, Rural Women in Oudh, 1917-47: Baba Ramchandra and the Women Question', in Kumkum Sangari and Sudesh Vaid (ed.) Recasting Women: Essays in Indian Colonial History (New Delhi: Kali for Women, 1989).

[8] Thapar, Suruchi, Women as Activists: Women as Symbols: A study of Indian National Movement, Feminist Review, No. 44, Nationalism and National Identities, 1993, 81-96.

[9] Thapar- Bjorkert, Suruchi, Gender, Nationalism and the Colonial Jail: A Study of Women Activists in Uttar Pradesh, Women's History Review, 7(4), 1998

[10] Thapar- Bjorkert, Suruchi, Nationalist Memories: Interviewing Indian Middle Class Nationalist Women, Oral History, 27(2), 1999, 35-46. 